\title{
Application of the OEE tool as a proposed increase in productivity in grain drying systems
}

\author{
Aplicação da ferramenta OEE como proposta de aumento da \\ produtividade em sistemas de secagem de grãos
}

\author{
Darlan Marques da Silva ${ }^{1}$ (D), Higor Marques de Oliveira ${ }^{1}$ (D) \\ ${ }^{1}$ Universidade de Rio Verde - UniRV, Faculdade de Engenharia de Produção, Rio Verde, GO, Brasil. \\ E-mail: darlan@unirv.edu.br; higormarques21@hotmail.com
}

How to cite: Silva, D. M., \& Oliveira, H. M. (2020). Application of the OEE tool as a proposed increase in productivity in grain drying systems. Gestão \& Produção, 27(4), e4964. https://doi.org/10.1590/0104$530 \times 4964-20$

\begin{abstract}
Companies nowadays seek to gain advantages over their competitors by using tools that converge them to more efficient and effective processes. With this competitive scenario, the use of the Global Equipment Effectiveness (OEE) indicator has grown. In this sense, the present study aims to propose improvements in the productivity and management of the maintenance of grain drying operations, through the analysis and OEE calculations of the process. Developed in a grain processing and storage unit, the Availability, Performance and Quality indices were calculated using historical data recorded in Excel spreadsheets and analyzed in graphs. The evaluations carried indicated satisfactory performance regarding maintenance scheduling due to the high availability rates of the equipment. As for the results obtained for performance, it was possible to observe the variables influencing the productivity and to point out improvements to the process. The observations made in the scope of quality surrounded the effects that the high moisture contents of the grains cause to the drying process. In view of this, it was possible to conclude that the losses between the indexes that compose the OEE have a high correlation.

Keywords: Availability; Global equipment efficiency; Performance indicator.

Resumo: As empresas, na atualidade, buscam obter vantagens frente aos seus concorrentes com emprego de ferramentas que as façam convergirem para processos mais eficientes e eficazes. Com esse cenário competitivo, o uso do indicador de Eficiência Global dos Equipamentos (OEE - Overall Equipment Effectivenes) tem crescido. Nesse sentido, o presente estudo tem como objetivo propor melhorias na produtividade e na gestão da manutenção das operações de secagem de grãos, por meio da análise e dos cálculos de OEE do processo. Desenvolvido em uma unidade de beneficiamento e de armazenamento de grãos, foram calculados os índices de Disponibilidade, Performance e Qualidade, mediante dados históricos registrados em planilhas de Excel e analisados em gráficos. As avaliações realizadas indicaram desempenhos satisfatórios quanto à programação da manutenção, em razão dos altos índices de disponibilidade dos equipamentos. Quanto aos resultados obtidos para performance, foi possível observar as variáveis impactantes à produtividade e apontar melhorias ao processo. As observações realizadas no âmbito da qualidade circundaram os efeitos que os altos teores de umidade dos grãos causam ao processo de secagem. Em vista disso, foi possível concluir que as perdas entre os índices que compõem o OEE possuem alta correlação.
\end{abstract}

Palavras-chave: Disponibilidade; Eficiência global de equipamentos; Indicador de desempenho.

Received July 27, 2018 - Accepted Dec. 19, 2018

Financial support: None.

This is an Open Access article distributed under the terms of the Creative Commons Attribution License, which permits unrestricted use, distribution, and reproduction in any medium, provided the original work is properly cited. 


\section{Introduction}

Brazil is a country that has several aspects that privilege the practice of agribusiness. Its great territorial extension, abundance of fresh water, relief and favorable climate make this activity one of the main economic sources of the national territory. According to data from the Confederação da Agricultura e Pecuária do Brasil (CNA, 2016) and the United States Department of Agriculture (USDA, 2017), agribusiness accounted for approximately $21.5 \%$ of Brazilian national Gross Domestic Product (GDP) 2016, with emphasis on corn and soybean crops. Soybean ranks second in the world ranking, with production of 113.923 million tons, being surpassed only by the United States, with 117.208 million tons in the 2016/2017 harvest (EMBRAPA, 2017; USDA, 2017).

The central-west region of the country, in the last five years, has recorded the greatest advances in relation to the planting of corn and soybeans, according to surveys by the Companhia Nacional de Abastecimento (CONAB, 2017). Currently, it accounts for about $36.70 \%$ and $65.37 \%$ of Brazilian corn and soybean production, respectively. For the 2017 crop, the Instituto Brasileiro de Geografia e Estatística (IBGE) expected a $19.5 \%$ increase in soybean crop in relation to the $2016 \mathrm{crop}$ (IBGE, 2017). These constant additions in the production of grains end up reflecting in the storage units, demanding bigger and more sophisticated controls.

The maintenance of their biological properties depends mainly on the handling of the grains during the storage process, otherwise they will not be available to supply the demand when requested (Burkot, 2014). In the post-harvest period, one of the main processes that precede the storage is the drying of the grains (Ribeiro et al., 2005), because by reducing the humidity percentage, it is possible to satisfy the conditions necessary for storage (Weber, 2005).

In this context, it is common for agribusinesses to invest heavily in this sector in order to produce, benefit and export products from the countryside. With competitiveness in this market, and in line with the increase in demand, companies need to be prepared to deal with this movement, and for that, knowing the capacity of their plants is crucial. Good asset management is one of the measures that can enable industries to increase productivity, reduce operations costs, and improve quality. An indicator that allows visualization of these aspects is the Overall Equipment Effectivenes (OEE), since its focus is focused on measurements of the overall equipment efficiency (Stortte et al., 2014).

The present case study was developed in a Grain Processing and Storage Unit (GPSU), in a multinational company in the commodities sector, located in southwestern Goiás, with the objective of proposing improvements in productivity and maintenance management of drying operations of grain by analyzing OEE calculations, identifying losses related to maintenance, production and quality, from the understanding of the process and the tool studied.

For this, it was subdivided into five sections, whose second, third and fourth sections discuss, sequentially, the grain drying process, the indicators (performance, availability and quality) in the decision making and the OEE as a tool to reduce losses, with the purpose of knowing the process in which the research was developed and of bringing correlated works. In section number five, the methodological procedures adopted throughout the work are included, and in the sixth section, the discussion of the results obtained by the research is found. The last section brings the closing of the paper with a conclusive presentation. 


\section{Drying of grains}

During harvest periods, some measures are proposed in order to guarantee the quality of the product, one of them is to advance the harvesting periods in order to preserve the planting of the pest attack. This measure results in the generation of products with high humidity indexes. Higher indices that directly affect the grain conservation process, at which time the drying process demonstrates its excellence in the post-harvest period (Ribeiro et al., 2005).

The efficiency of keeping grain quality for storage through the drying process is based on the precepts that water is used as a source in the metabolic development of the microorganisms, so it is noticed that, with control in the moisture levels of the product, it is quality during storage periods (Rodrigues, 2010).

According to Schmidt et al. (2017), the drying process by displacement of hot air through the mass of grains is the most usual. During its execution, there is the simultaneous occurrence of heat and mass transfer until the equilibrium with the environment is reached, its duration being determined from the relation between the desired water content, the initial water content and the performance of the dryer (Biagi et al., 2002; Ribeiro et al., 2005; Schmidt et al., 2017).

According to Silva (2004), the drying process occurs in three stages: in the first, the air heated by the furnace of the dryers transfers heat to the grains that, in consonance, transmit moisture to the layer of air that surrounds it, which is called microclimate. In the next phase, the microclimate vapor migrates into the drying air because the relative humidity of the microclimate (URg) is greater than the relative humidity of the air surrounding the grain (URac). In the third and last step, the drying air becomes exhaust air (URae) as a function of its temperature drop by means of the transfer of heat and the increase of its relative humidity by mass transfer, as shown in Figure 1.

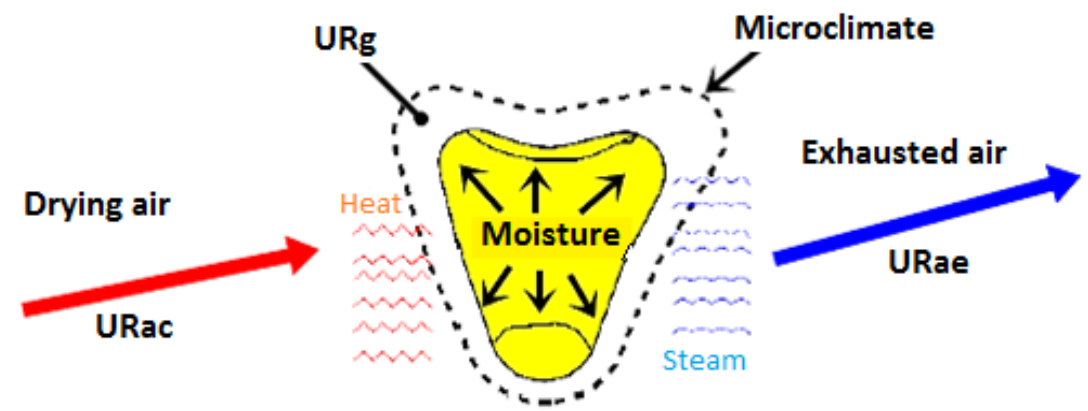

Figure 1. Grain drying process. Source: Silva (2004).

In Brazil, the most used dryer model is the mixed flow also known as the cascade type, which is fed from the thermal energy released by the wood burning in the furnace. It consists of a tower in which $2 / 3$ of its construction is intended for drying and a remaining $1 / 3$ is available for the cooling of the grain mass to the storage temperature. They are available in the market with capacities between 15 and 250 tons/hours (Schmidt et al., 2017).

Because they are responsible for most of the electric and thermal energy consumption based on the burning of fuels, the dryers receive special treatments in the grain processing units. In addition to their high operating costs, they are responsible for maintaining harvest quality for storage. However, the poor operation of these 
equipment can cause disruption to the physical properties of the grains, especially when intermittent drying is required, in which the grain mass does not reach the expected moisture content, and it is necessary to recirculate the product through the dryer (Silva, 2006).

Silva (2006) also points out that for a good operation of the equipment, it is important to know the input variables, the system parameters and the output variables. The input variables are the initial water content of the product, the type of product and the index of broken and cracked grains. The capacity of the elevators, power of the electric motors, required air flows and product speed through the dryer are the parameters of the system. For the output variables, the drying time, the final water content of the product, the exhaust air temperature, the index of cracked and broken grains and the consumption of firewood and electric energy are considered.

In order to be able to manage all these variables, industries commonly make use of tools that monitor processes. These tools, in general, are aimed at monitoring and controlling aspects of greater relevance. Indicators help to make management more efficient and process more efficient.

\section{Indicators}

The need for assertive decision making by managers on adverse conditions requires strategies capable of demonstrating information on production processes in real time. In this context, performance indicators prove to be effective in quantifying the results obtained and providing evaluations of process improvements, as well as verifying that the achievement of goals and targets occurred as planned (Vinha \& Mota, 2014; Silva et al., 2015). Among the indicators, the one related to performance, has been undergoing measurement applications, mainly, regarding equipment.

\subsection{Performance indicator}

For the maintenance of assets, the performance indicators support the planners and maintainers in the behavioral evaluations of machines and equipment, proposing the most appropriate moment for action. In addition, measuring the performance of the equipment contributed to the success of the industrial companies, after all, they are determinants for productivity (Marques, 2014).

Gonçalves (2014) demonstrates in his work with performance indicators the evaluation of the philosophy adopted in the maintenance management of an airport and its effective improvement in the solutions of the needs of the assets and in the results sought by the organization. For Marques (2014), it is imperative that the maintenance sector knows, follows and plans its use, thus, its revenues and costs are better managed. According to Marques (2014), the indicators supported the process of implementing a new methodology for maintenance planning and scheduling, generating benefits with cost reduction, increased availability of equipment, reduction of accident risks and growth in service quality performed.When talking about maintenance, it is extremely important to refer to the indicator of the equipment availability. 


\subsection{Availability indicator}

The availability indicator is closely related to the reliability function of an item and can be defined as the measurement of the probability that the equipment / item is available at a given instant of time (t) (Ammara et al., 2016; Jaimes \& Candia, 2018).

For Erkoyuncu et al. (2017), the availability indicator is an auxiliary feature in reducing maintenance costs, and allows planning decisions to be made efficiently, exemplifying a case by the United Kingdom Ministry of Defense. However, Ammara et al. (2016) explain that the indicators of equipment performance, which can be extended to availability, it is essential to evaluate them before taking measures that can lead to optimization or even improvement of processes.

Optimization is an excellence that must be tied to the quality indicator, since any type of improvement (process or products/services) must be quantified in a way that meets the customer's expectations.

\subsection{Quality indicator}

The quality indicator refers to the quantity of products that can meet the specifications, being measured by a relation between the number of products that meet these specifications and the actual quantity produced (Dunn, 2015).

For Andersson \& Bellgran (2015), OEE, when related to quality, presents a clear correlation with industrial productivity, both increasing simultaneously. Remetendo-se a qualidade da secagem da soja, quando esse grão apresenta elevado estado de unidade pode levar a perda da sua funcionalidade e do seu estado nativo, devido às duras condições que o cereal é submetido (Xing et al., 2018).

The next section deals with OEE, which aims to quantify and evaluate production losses through the asset management process. The Overall Equipment Effectivenes tool has gained an emphasis on many companies, especially those that need to ensure the high availability rates of their equipment (Silva \& Derzi, 2016).

\section{The overall efficiency of the equipment by OEE}

OEE (Overall Equipment Effectivenes) is a tool used in asset performance management. It was developed according to the Total Productive Maintenance (TPM) methodology, based on the transition from corrective to preventive maintenance, in search of "zero stop", thus reducing the costs of equipment breakdowns and stoppages in the production process (Girão et al., 2016). Still according to Girão et al. (2016), the first company to implement the TPM philosophy was part of the Toyota group which, in return, received the industry excellence award in Japan due to the effectiveness of the implemented program.

Raposo (2011) points out that the search for "zero stop" occurs to eliminate the six large losses, they are: breaks and failures; small stops; loss of speed; start-up; and rework. Eliminating such losses is one of the great provocations of the TPM methodology, and for this, five practices are structured. The first one is in the quest for efficiency improvement, in which losses that can occur throughout the process are studied; the ensuing practice involves the dissemination of autonomous maintenance, in which operators are responsible for part of the maintenance; the third one refers to maintenance planning, in which work methods and roadmaps are determined for each machine. Afterwards, the training of the personnel is carried out, so that the best 
performance of the team is possible, and finally, the management of the equipment from the project, avoiding complex maintenance (Slack et al., 2002).

Still, according to Slack et al. (2002), the total productive maintenance demonstrates that the availability of the equipment is not only about the maintenance team, but everyone, who can contribute in any way. This concept makes clear the importance of the interaction between men and machines, and is even clearer when visualized according to the eight pillars that underpin the TPM work philosophy, which are: autonomous maintenance; planned maintenance; specific improvements; education and training; quality; initial control; Administrative TPM; TPM safety, hygiene and environment (Macon et al., 2010).

Referenced in the Brazilian bibliography as Global Equipment Efficiency, OEE was created in the 1960s by Seiichi Nakajima, with the aim of evaluating manufacturing through three indexes: availability, performance and quality (Leal et al, 2013). The combination of these three factors demonstrates the overall efficiency of the equipment, however, the individual analysis of each one of them allows identifying which points require more attention (Raposo, 2011).

Its worldwide dissemination emerged in accordance with the adoption of the Toyota Production System and Lean Manufacturing methodologies by companies, which increasingly seek zero loss. As a three-dimensional indicator, it reflects well the main losses that occur in an equipment, and yet allows other functionalities, such as capacity planning, process control, process improvement and quantification of costs of losses (Silva, 2009).

Stortte et al. (2014) point out that the use of OEE in its study, brought possibilities of improvements in the efficiency of the mill and the boiler, in which the losses of availability could be qualified and quantified, directing the adoption of measures that increase the performance of the system. The causes with the most relevant diagnoses, according to the indicator, were the lack of steam and mechanical maintenance, demonstrating the openness for its use to be expanded to other critical points in the industry. Silva \& Derzi (2016) are other authors who demonstrate that, with the OEE survey and evaluation, productivity gains are possible. In its work on the conformation of aluminum caps for beverages, it was possible to reduce the idleness during the process, reflecting an increase of the order of $10.5 \%$ in the manufacture of the caps.

According to Rigoto \& Natti (2014), the application of the calculations of the overall efficiency of the equipment in its study revealed the need of the exchange of two forklift trucks for better use of the time available for operation. This resulted in increased productivity in the vibration production line during the concrete pipe manufacturing process. Indirectly, the indicator had a role in reducing maintenance costs once a preventive maintenance program was in place, minimizing the impacts caused by sudden machine breaks.

With all this scenario of applications and improvements, companies considered excellence when applied the OEE, have the result equal to $85 \%$. However, in order to achieve the "title" of world-class OEE, it is not enough to only achieve such an outcome, its availability, performance and quality indexes must be equal to $90 \%, 95 \%$ and $99.9 \%$, respectively. It is worth emphasizing that these values are not always relevant for all organizations, varying according to the methodology adopted by each one in its processes (OEE, 2017).

Knowing that the OEE has its focus aimed at reducing or eliminating the waste of productive processes. Whether of time and / or resources, its use is indicated for those equipments that constitute the bottlenecks. Thus, the results need to indicate the points 
of improvement (Pintelon \& Muchiri, 2008; Raposo, 2011). Raposo (2011) shows that, for this, it is important that the data for the calculation of the indicator have a high degree of reliability, since, doubtful information can lead to decisions that lead to increased waste, going against is proposed.

Next, the indicators that make up the OEE will be presented in an equated way in the context of the present case study, in a more detailed way, for a better understanding.

Therefore, the OEE can be translated by Equation 1:

$O E E=A x P x Q$

Wherein:

a) Availability $(A)$ : it is the index that refers to the percentage of the time the equipment or machine was in operation in relation to the total time, due to the stops by failures, maintenance and setup (Pereira, 2012). For the present study it will be calculated from Equation 2.

$A=((T T-D) / T T) \times 100$

Where TT is the Total Time (in hours (h)) is the number of hours available in the calendar in the period in question and the $D$ Downtime $(\mathrm{h})$ is the number of hours that the equipment was unavailable due to failures, maintenance, setup, cleaning, among others.

b) Performance $(P)$ : is the percentage relation between the rated capacity of the equipment and its effective performance. In this respect, speed falls due to anomalies and small stops that can impact performance are analyzed. For the present study, it will be calculated from Equation 3.

$P=((N P-E F) / N P) \times 100$

Where the $N P$ is the Nominal Performance is the capacity determined by the manufacturer in design and the $E F$ represents the Effective Performance, the volume being dried per hour in reality, both performances in tons per hour (ton $/ \mathrm{h}$ ).

c) Quality $(\mathrm{Q})$ : this indicator shows the part of the production defective or that generated rework. For the drying process the percentage ratio between the total dry volume and the volume that needs to be passed through the dryer more than once, that is, be reprocessed, will be analyzed. Their results will be obtained according to Equation 4.

$Q=((T V D-I D V) / T V D) \times 100$

When $T V D$ is the Total Volume Drying (ton), which corresponds to the entire volume dried in the analyzed period and the $I D V$ is the Intermittent Drying Volume (ton), it corresponds to the quantity of products that have been dried more than once. 
The next topic demonstrates the materials and methods adopted during the development of this study.

\section{Methodological procedures}

In this section, the methods used to carry out the study will be explored to achieve the goal. It is characterized as a case study, for evaluating occurrences of true everyday life. In addition, it is a quantitative approach, since it takes into account the analysis of indicators that are based on mathematical methods, in order to quantify the losses in the productive processes (Prodanov \& Freitas, 2013).

The beneficiation and storage plant of this study receives the grains by truck and dispatches them by the modal waterway. The equipment studied was two mixed flow dryers with production capacity equivalent to 60 ton/h each, working 24 hours and seven days a week in the harvesting periods. Operators feed them with firewood by manually during the drying process.

The data collected for this research were recorded by the organization through spreadsheets. They refer to the records of the volumes dried in the months of January to April of 2017, period that corresponds to the movement of soybean. In addition, there was also assistance from the area manager. The tabulated values showed the times in which the equipment was in full operation and the times of stops due to breaks or failures, able to translate the availability of the asset, besides the time spent to perform the operation with certain volumes and their obtained results, allowing the calculations of performance and quality.

All calculations and graphs presented in this research were developed using spreadsheets in Microsoft Excel16 ${ }^{\circledR}$ and with the help of Minitab1 $7^{\circledR}$. From then on, the results obtained were discussed and analyzed during the next sections, with the purpose of proposing improvements in the performance of the system according to the methodology studied.

\section{Results and discussions}

Before starting the discussion about OEE, due to the criticality defined for the process as the amount dried tons per hour (ton $/ \mathrm{h}$ ). It was used the verification of uniformity of the process with the application of the efficiency indicator, from a comparison of the means $(\mu)$ according to Figure 2, which was considered an $\alpha=0.05$ or $5 \%$ error and a confidence interval of $95 \%$.

The hypotheses raised were:

$$
\left\{\begin{array}{l}
H_{0}: \mu_{\text {January }}=\mu_{\text {February }}=\mu_{\text {March }}=\mu_{\text {April }} \\
H_{1}: \mu_{\text {January }} \neq \mu_{\text {February }} \neq \mu_{\text {March }} \neq \mu_{\text {April }}
\end{array}\right.
$$

In that $H_{0}$ is the null hypothesis, which states that all averages are equal for all months (January, February, March, and April) and $H_{l}$ is the alternative hypothesis, noting that not all averages are equal. 


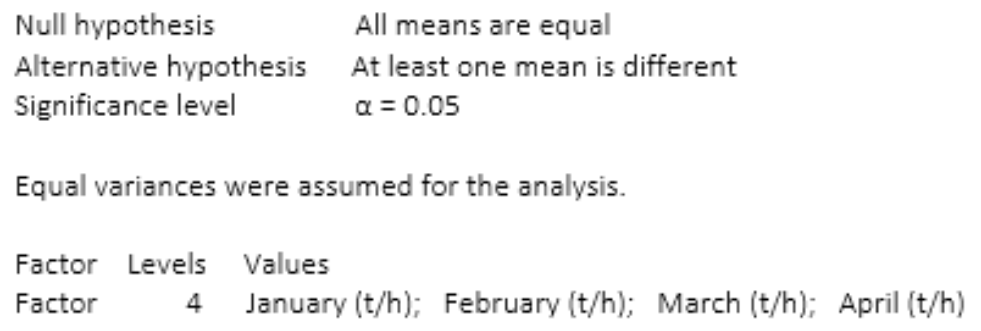

Analysis of Variance

$\begin{array}{lrrrrr}\text { Source } & \text { DF } & \text { Adj SS } & \text { Adj MS } & \text { F-Value } & \text { P-Value } \\ \text { Factor } & 3 & 1875 & 624.9 & 1.62 & 0.189 \\ \text { Error } & 97 & 37382 & 385.4 & & \\ \text { Total } & 100 & 39256 & & & \end{array}$

Model Summary

$\begin{array}{rrrr}\text { S } & \text { R-sq } & \text { R-sq (adj) } & \text { R-sq (pred) } \\ 19.6311 & 4.78 \% & 1.83 \% & 0.00 \%\end{array}$

Figure 2. Test $F$ of the means of soybean processing. Source: Exit of Minitab17 ${ }^{\circledR}(2018)$.

The p-value was $(0.189>0.05)$, so it was concluded that all means are equal. To prove this fact, the Tukey test was performed for multiple comparison of means (Figure 3). This method consists in obtaining intervals between all the factors and those that pass through 0 (zero), meaning that the averages compared are the same.

As can be seen in Figure 3, the test applied to the combinations between all the pairs of the study months, in their entireity generated by the Minitab $17^{\circledR}$, cross the transverse line of zero, demonstrating that there is really no significant difference in pairs.

Figure 4 shows that the average values are concentrated somewhat below $100 \mathrm{ton} / \mathrm{h}$, to the detriment of the capacity of the industrial process which is 120 ton/h. Highlight for the month of March (95.51) ton/h with the highest production and for April (85.52) ton/h with the lowest value. The month of April presented a lower value due to the end of the harvest, a period that arrives less raw material to be processed. One factor that contributed to the lack of better average values was emergency shutdowns due to process failures. The variability was most strongly concentrated in January and February, because of the corrective maintenance and preventive maintenance stops, as well as equipment adjustments for product receipt at the beginning of the harvest. 


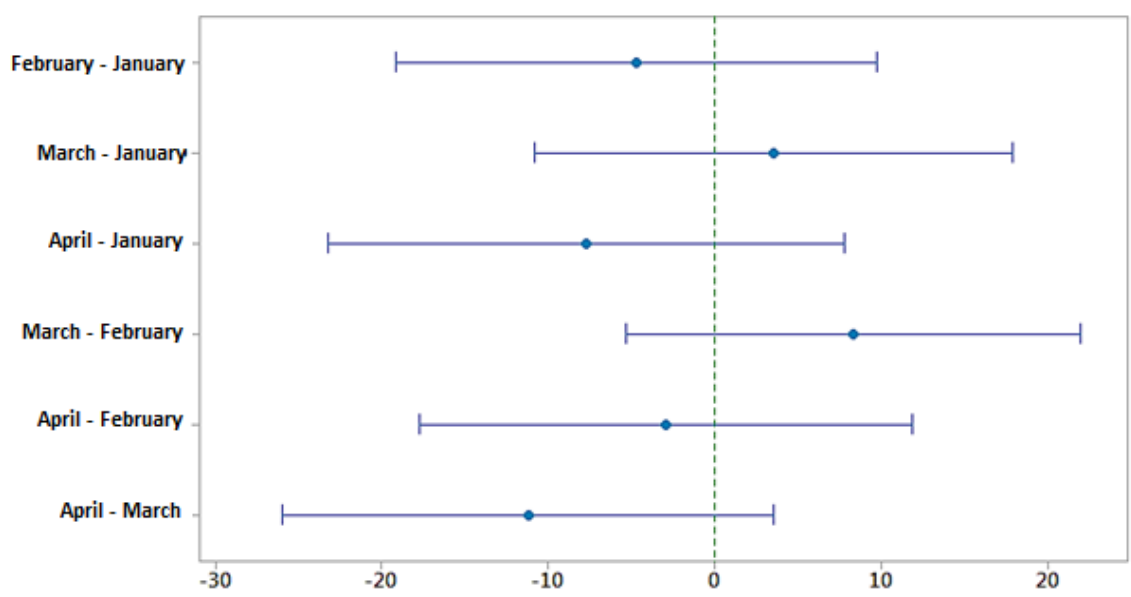

Figure 3. Tukey test for quantity ton/h at months. Source: Minitab17 ${ }^{\circledR}$ output (2018).

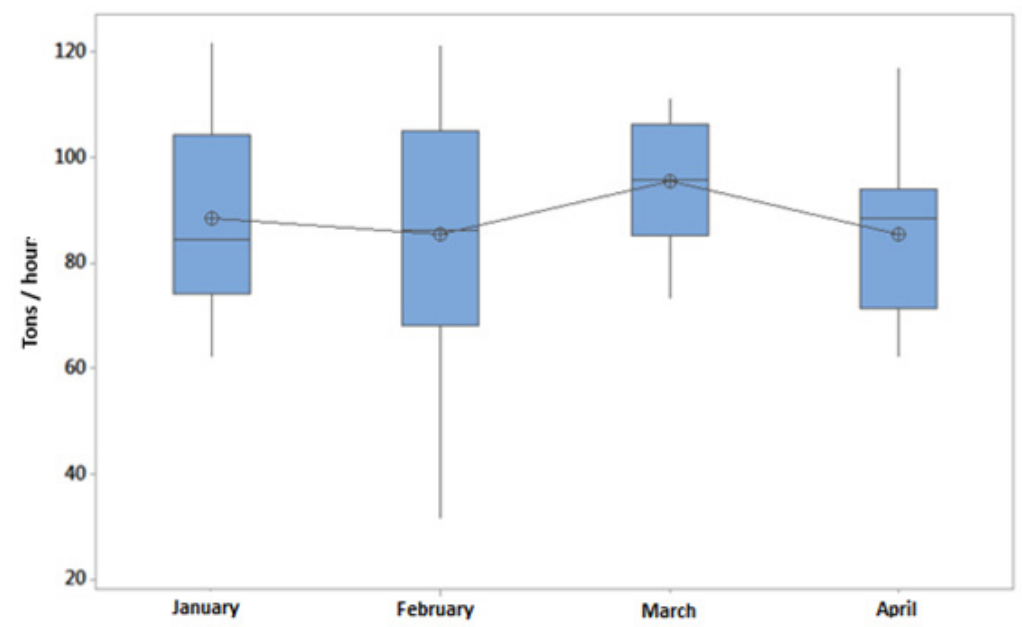

Figure 4. Behavior of means and variability ton/h by month. Source: Minitab17 ${ }^{\circledR}$ output (2018).

In order to validate the model, a residual data analysis was performed, according to Figure 5. The Normal Probability Chart should contain the plotted points close to the line, some are less close, due to special causes that appeared (stops and large quantity processed in just one day), the Versus Fits measuring the dispersion of the data, with a balance of the points (+ and -) for the months and the Histogram with mean around zero. What, due to the presence of very few anomalies already mentioned, the normality was not violated. 

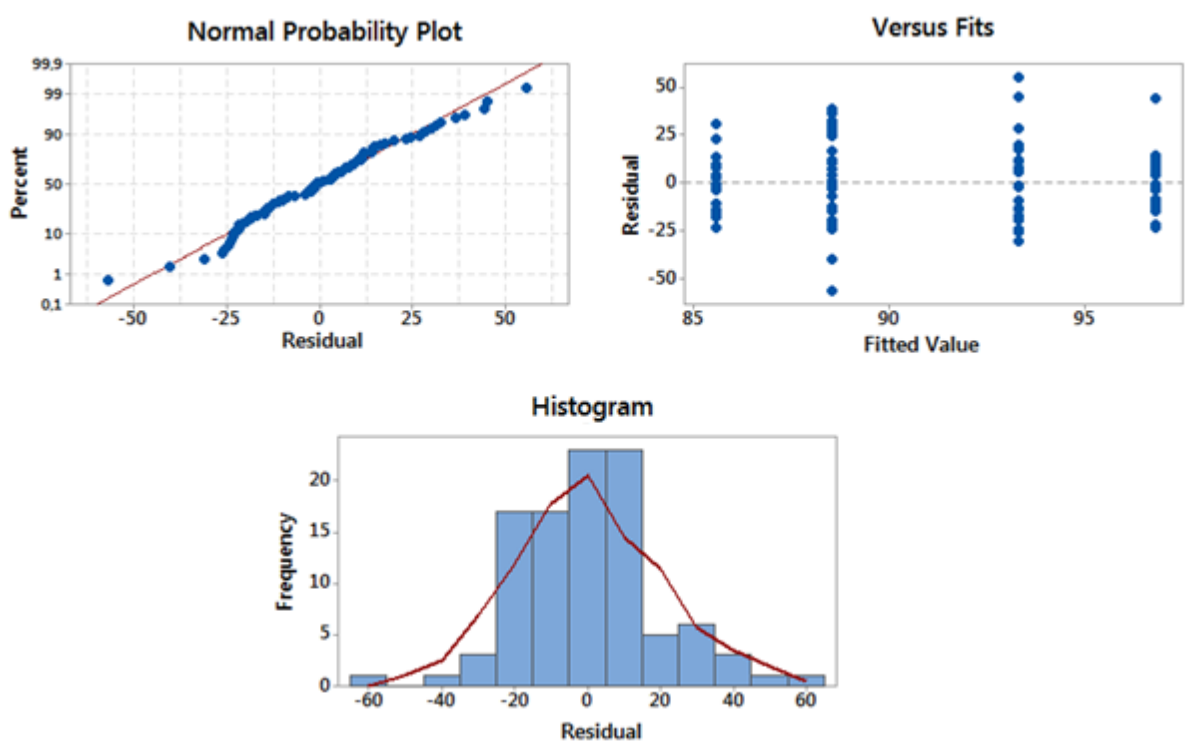

Figure 5. Residual Graphical Analysis. Source: Minitab17 ${ }^{\circledR}$ output (2018).

Because it is a process that has high installation and operating costs, it is important that its efficiency is monitored closely, reducing its losses to the maximum. In this respect, the application of OEE has emerged as a pillar for the search for improvements in the process. For a better understanding of the indicator, it is important that each of its indices be observed and judged separately. However, the first results presented translate the overall efficiency values of the equipment and its evaluation in general, aiming at promoting a prior evaluation of the results obtained and directing the research focus to the index that merits the greatest efforts.

Thus, with the necessary data in hand, it was possible to measure the values of each of the three components for monthly monitoring and then obtain the total value of the OEE for the entire period in question. According to Equation 1, product between availability, performance and quality could define the overall efficiency of the drying process under analysis. The results obtained were plotted on the graph represented by Figure 6 .

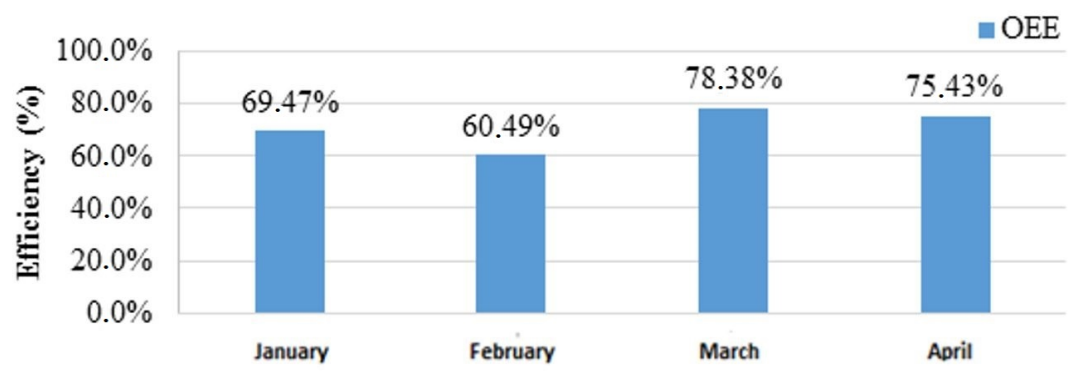

Figure 6. Overall Equipment Efficiency (OEE) (\%). Source: Own authors (2017).

Based on the data presented in Figure 6 , it is possible to understand that the OEE values are varying between $60.0 \%$ and $80.0 \%$, resulting in a $71.16 \%$ overall efficiency rate on average for the months of January to April 2017. A priori, there is an 
improvement gap equal to $28.84 \%$, however, in a comparative analysis with world class value, this gap becomes $13.84 \%$. Nevertheless, with these observations alone, evidence of the losses in the process becomes almost impossible. However, before beginning the index-to-index assessments, one of the quality tools was used to track which metrics the losses were most compelling.

The quality tool used was the Pareto Chart, also known as the $80 / 20$ principle, which is capable of demonstrating that $80 \%$ of the problems are from $20 \%$ of the causes, that is, $20 \%$ of the reasons generate $80 \%$ of the disorders. Thus, attacking these $20 \%$ of the sources, $80 \%$ of the obstacles will be solved (Peinado \& Graeml, 2007).

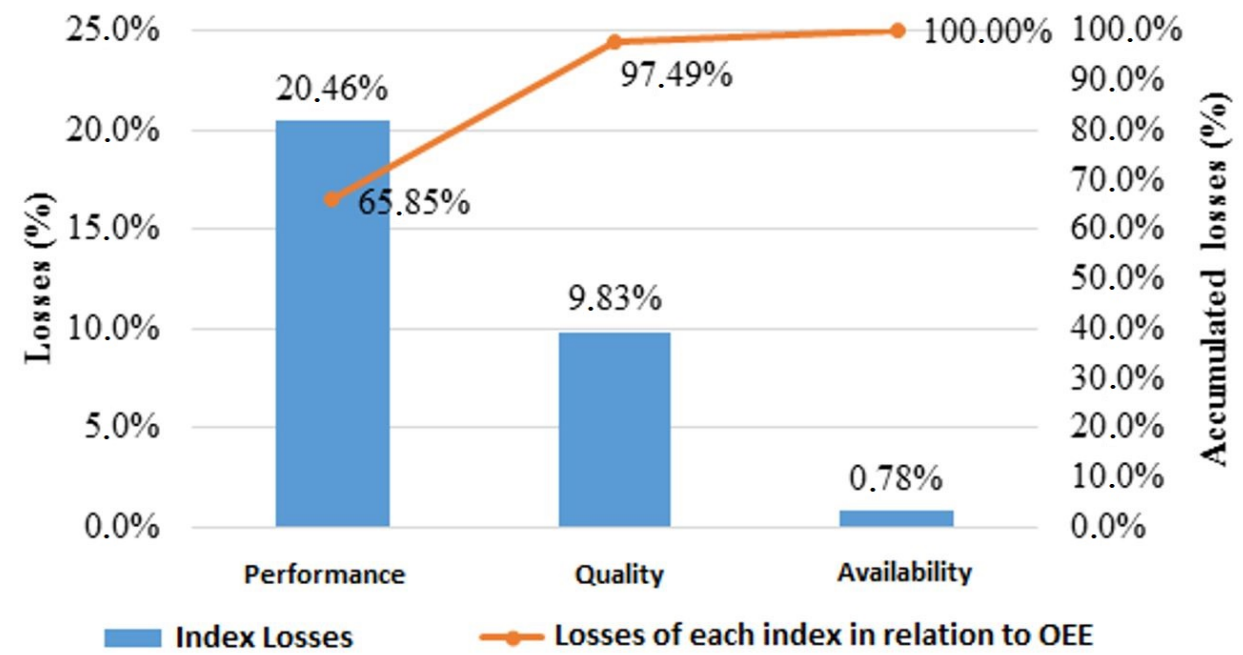

Figure 7. Global Efficiency Losses (\%). Source: Own authors (2017).

The use of the Pareto Chart provided the decision as to which of the items should look more effectively. With a quick examination, the diagnosis is given, the main losses of the process are related to the performance of the equipment. In this context, the next paragraphs bring a more detailed evaluation of each index, starting with availability and ending with quality, however, focusing mainly on the performance section. Figure 7 shows, in order, the index with the highest frequency of efficiency losses in relation to the lowest frequency index.

The first aspect analyzed among the three indices was the time when the equipment was really available. For this, all instants in which the system was not producing, such as scheduled stops, maintenance and cleaning, were subtracted from the calculation, according to Equation 2. The survey period consisted of 2880 hours, of which 2857.05 hours the equipment was in full operation. Figure 8 shows the scenario of availability of equipment during the period studied. 


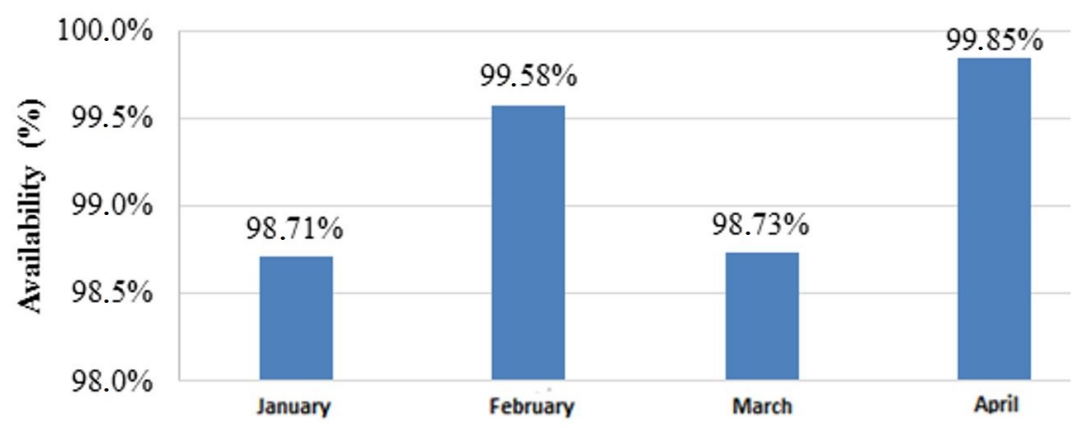

Figure 8. Availability of Equipment (\%). Source: Own authors (2017).

The average availability recorded reached the considerable $99.22 \%$. Observing Figure 8 it is possible to notice the very expressive values of each month. In the case of equipment, these numbers can be considered as an excellent index of availability even if compared with the value of world-class. Based on this number, it is hypothesized that the adopted maintenance plan demonstrates effectiveness, after all, the process losses recorded for the maintenance criterion are low. During inter-harvest periods, operation with high moisture content products is greatly reduced, promoting direct storage without requiring drying to occur, providing sufficient time for adjustments, maintenance and improvements, thus reducing unexpected breakages. Although the results obtained demonstrate high levels of availability, frequent monitoring of this indicator will allow maintenance staff to measure their performance and provide greater operational reliability to the process.

After all, in a more current view of maintenance concepts, its focus is on maintaining the functions of machines and equipment as well as designed. This scenario makes maintenance teams increasingly focus on strategies that balance the availability and cost factor, that is, find the satisfactory point between these two aspects (Garcia, 2014; Brusius, 2016). Therefore, when there is equipment that provides good levels of availability, managers have greater reliability in the production systems and / or processes, making decision making easier.

The performance of the equipment, according to the index that makes up the OEE, is the percentage relation between the actual and the projected performance, this indicator places great emphasis on productivity for evidencing how the system is behaving. For their calculation, the quantities produced in proportion to the operating time were used and compared to the nominal performance, as well as exposed in Equation 3.

The results obtained for this criterion are demonstrated in Figure 9, from its observation, it is noticeable that the performance losses are larger when compared to the ones by availability. The average performance index recorded in all intervals corresponds to $79.50 \%$, that is, there is room for improvement of equipment performance by $20.46 \%$. Although there are important variables for the productive capacity of the dryers, some of them are subject to the influence of the managers, others not so much, implying in careful analysis of this indicator. 


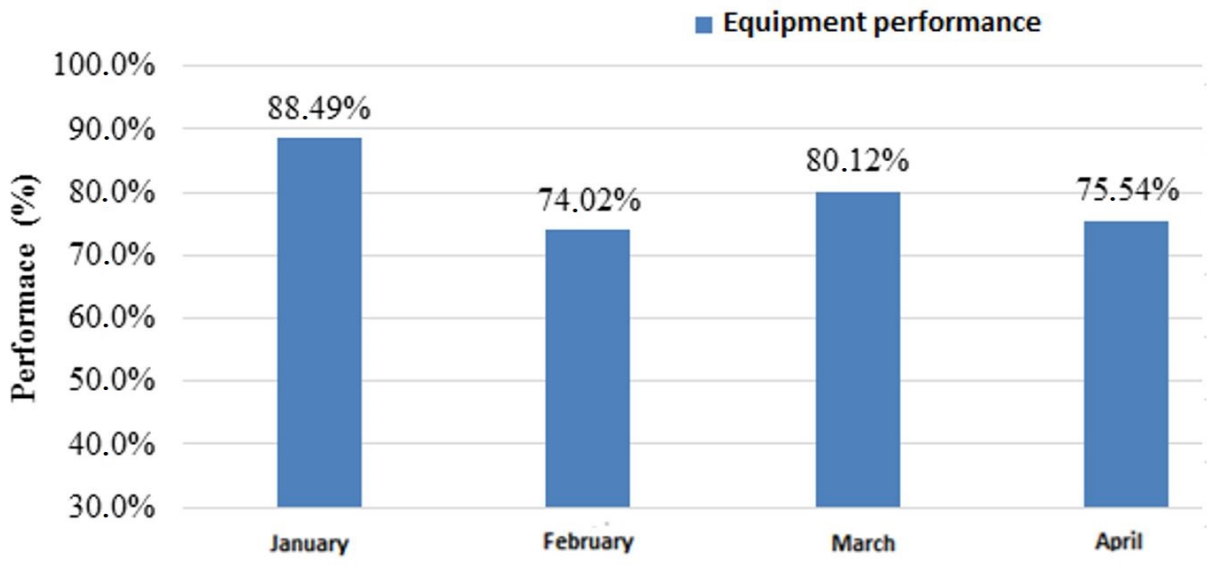

Figure 9. Equipment Performance. Source: Own authors (2017).

With the theoretical study and observations of the operation of the drying process, it is possible to indicate some improvements relevant to the process. When the equipment receives a high percentage of impurity, its performance is impacted, being necessary that the grains go through a process of pre-cleaning for the removal of materials coming from the harvest (stems, leaves, straws, clods, among others). During this process, the grains are subjected to sieving, in different granulometric meshes, until the percentage of impurity is reduced. This process, in addition to decreasing fuel consumption and fire risks, provides greater effectiveness during drying because these materials obstruct heat and mass transfer between grains and drying air (CASEMG, 2017). For this aspect, a better adjustment to the sieves may be suggested for greater removal of impurities from the beans, before entering the dryer.

Another variable of performance impact observed during the study is the need for the constant supervision and performance of the operators regarding the variations of temperature of the drying air, increasing or decreasing the fuel supply. Schmidt et al. (2017) state that this type of empirical control brings inefficiency to the process because it is more prone to errors. As an improvement to this procedure, a feasibility study of the implantation of intelligent temperature controllers, which regulates the temperature variations by means of thermostats, is necessary, increasing the efficiency of the process. Its adoption by the UBAG has grown (Rodrigues, 2010).

There are many controversies regarding the quality of grains, most of which are compared with the purpose of the process or its final use (Fernandes \& Marinho, 2016). Thus, the most consistent way to analyze the results that surround the quality aspect for the present study is the purpose of the grain drying process, that is, to satisfy the cereals with adequate moisture content for long-term storage without losses.

The results obtained from Equation 4 are based on the losses generated to the process quality by reworking, where it was not possible to reach the pre-established moisture storage requirements. Thus, the evaluations focus on the quality of the process and not directly on the quality of the product. As for the process rework, they are called intermittent drying, in which the product is recirculated by the dryer until it reaches the desired content, and usually occurs when the initial moisture content exceeds about $4 \%$ of the desired final percentage (Silva, 2006). Figure 10 shows the percentages of soybean dried by the continuous process, without the need to recirculate the product by the equipment. 
However, the results indicate that, over the months, the rates of products dried by the intermittent process decreased, thus increasing the quality of the process. The increases recorded in the graph over the study period are related to the distance from the beginning of the harvest, in which the grains have higher moisture content. These increases in quality, in turn, are relevant to the operational costs, taking into account the reduction of the residence times of the grain mass in the equipment, therefore, the energy consumption is lower, both electric and thermal, obtained from combustion.

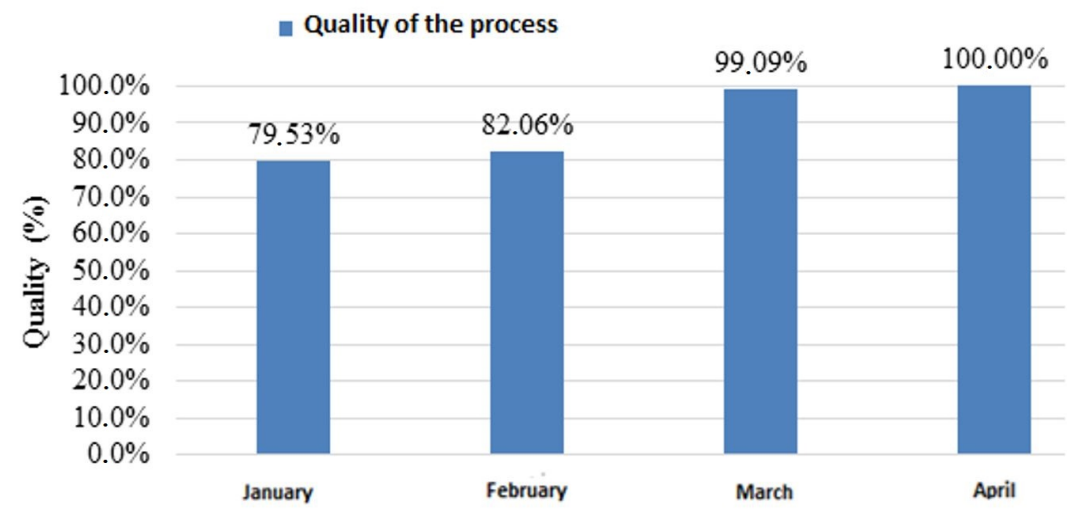

Figure 10. Quality of the Drying Process. Source: Own authors (2017).

When the product receives casters in the dryers, the truck unloading operation carried out at the UBAG is impacted. Its capacity is reduced due to the need to send the product discharged to the dryer, with this reaches the maximum capacity of the hoppers, adding the number of vehicles awaiting the discharge and consequently the costs of stay. Therefore, in order to assign higher quality indices to the process, it is important for managers and decision makers to know the capacity and bottlenecks of their processes by weighing the moisture content of the shipments.

\section{Conclusion and final considerations}

Through this study, the broad application of the OEE indicator is noted. Its use was able to identify the losses in the grain drying process associated to the availability, performance and quality pillars, aspects that can define the excellence and competitiveness among the organizations.

Regarding the availability of the equipment under study, the performance was really expressive, with a mean of $99.22 \%$. Emphasis is given to the effectiveness of the maintenance team's actions, since the main losses related to this index are related to this sector of the industries. However, the result obtained did not impede the progress of the study of improvements, on the contrary, allowed a better analysis of the other indexes.

The performance and quality criteria analyzed correlated, demonstrating an interdependence regarding the overall efficiency of the equipment. However, the approach to the improvement proposals emphasized equipment performance, the item that demonstrated the greatest losses and impacts to the OEE of the drying process. 
For future work, it is possible to evaluate the implementation of the improvements indicated here, as well as to validate the effectiveness of the management by the OEE indicator in real time. In addition, the quality criterion can be evaluated from the perspective of the quality losses generated by the drying process.

\section{References}

Ammara, R., Fradette, L., \& Paris, J. (2016). Equipment performance analysis of a Canadian Kraft mill. Part I: development of new key performance indicators (KPI). Chemical Engineering Research \& Design, 115, 160-172. http://dx.doi.org/10.1016/j.cherd.2016.09.019.

Andersson, C., \& Bellgran, M. (2015). On the complexity of using performance measures: enhancing sustained production improvement capability by combining OEE and productivity. Journal of Manufacturing Systems, 35, 144-154. http://dx.doi.org/10.1016/j.jmsy.2014.12.003.

Biagi, J. D., Bertol, R., \& Carneiro, M. C. (2002). Secagem de grãos para unidades centrais de armazenamento. In I. Lorini, L. H. Miike \& V. M. Scussel (Eds.), Armazenagem de grãos (pp. 289-308). Campinas: Instituto Bio Geneziz.

Brusius, W., Jr. (2016). Estratégia de manutenção centrada na confiabilidade para três maquinas de produção em uma empresa de transformação mecânica. Porto Alegre: Universidade do Vale do Rio dos Sinos.

Burkot, C. R. (2014). A qualidade desejada na secagem e armazenagem de grãos em uma cooperativa no município de Ponta Grossa - PR. Gestão e Organizações Cooperativas, 1(2), 39-50. Retrieved in 2017, October 14, from https://periodicos.ufsm.br/rgc/article/download/15479/pdf

Companhia de Armazéns e Silos de Minas Gerais S.A. - CASEMG. (2017). Secagem de grãos. Belo Horizonte. Retrieved in 2017, October 14, from http://www.casemg.gov.br/index.php/servicos/secagem-de-graos/

Companhia Nacional de Abastecimento - CONAB. (2017). A produtividade da soja: análise e perspectivas. Compêndio de Estudos CONAB, 10, 1-35.

Confederação da Agricultura e Pecuária do Brasil - CNA. (2016). PIB do agronegócio deve crescer de 2,5\% a 3\% em 2016, diz CNA. Brasília. Retrieved in 2017, August 12, from http://www.cnabrasil.org.br/noticias/pib-do-agronegocio-deve-crescer-de-25-3-em-2016diz-cna

Dunn, T. (2015). OEE effectiveness. Flexible Packaging: Materials, Machinery, and Techniques, 77-85. http://dx.doi.org/10.1016/B978-0-323-26436-5.00008-4.

Empresa Brasileira de Pesquisa Agropecuária - EMBRAPA. (2017). Soja em números (safra 2016/2017). Brasília. Retrieved in 2017, August 8, from https://www.embrapa.br/soja/cultivos/soja1/dados-economicos

Erkoyuncu, J. A., Khan, S., Eiroa, A. L., Butler, N., Rushton, K., \& Brocklebank, S. (2017). Perspectives on trading cost and availability for corrective maintenance at the equipment type level. Reliability Engineering \& System Safety, 168, 53-69. http://dx.doi.org/10.1016/j.ress.2017.05.041.

Fernandes, R. L., \& Marinho, M. S. (2016). Controle de qualidade na produção de milho: semente. In Anais do Simpósio de TCC e Seminário de Iniciação Científica. Brasília: ICESP.

Garcia, F. L. (2014). Proposta de implantação de manutenção preventiva em um centro de usinagem vertical: um estudo de caso. Tecnologia e Tendências, 9(2), 88-115. Retrieved in 2017, August 12, from 
http://periodicos.feevale.br/seer/index.php/revistatecnologiaetendencias/article/view/1342/2 075

Girão, A. H. F., Amorim, A. A., \& Masih, R. T. (2016). Análise do processo da aplicação da manutenção produtiva total no setor de tingimento de uma indústria têxtil. In Anais do XXXVI Encontro Nacional de Engenharia de Produção. João Pessoa: ABEPRO.

Gonçalves, D. F. (2014). Gestão da manutenção em edifícios: modelos para uma abordagem LARG (Lean, Agile, Resilient e Green) (Dissertação de doutorado). Universidade Nova de Lisboa, Lisboa.

Instituto Brasileiro de Geografia e Estatística - IBGE. (2017). Produção de cereais, leguminosas e oleaginosas - confronto entre as safras 2016 e 2017. Retrieved in 2017 , August 8, from http://www.ibge.gov.br/home/estatistica/indicadores/agropecuaria/lspa/lspa_201706_7.sht $\mathrm{m}$

Jaimes, M. A., \& Candia, G. (2018). Toppling of rigid electric equipment during earthquakes. Engineering Structures, 168, 229-242. http://dx.doi.org/10.1016/j.engstruct.2018.04.083.

Leal, F., Almeida, D. A., Parenti, L. V., Ferreira, J. S., Jr., \& Maurio, T. B. (2013). Adaptação do indicador OEE para análise de perdas produtivas relacionadas ao uso da energia elétrica. In Anais do XXXIII Encontro Nacional de Engenharia de Produção. Salvador: ABEPRO.

Macon, E., Caspani, F. C., \& Alonso, L. C. (2010). Total Productive Management (TPM). Bauru: Universidade Estadual Paulista.

Marques, A. P. (2014). Planejamento e programação na base: estudo de caso PETROBRAS UO/RIO. In Anais do XXXIV Encontro Nacional de Engenharia de Produção. Curitiba: ABEPRO.

OEE. (2017). OEE classe mundial. Retrieved in 2017, September 5, from http://www.oee.com.br/oee-world-class

Peinado, J., \& Graeml, A. (2007). Administração da produção: operações industriais e de serviços. Curitiba: UnicenP.

Pereira, N. N. (2012). Operação portuária (Apostila). São Luís: Curso de Especialização em Engenharia Portuária, UFMA-VALE.

Pintelon, L., \& Muchiri, P. (2008). Performance measurement using overall equipment effectiveness (OEE): literature review \& practical application discussion. International Journal of Production Research, 46(13), 1-45.

Prodanov, C. C., \& Freitas, E. C. (2013). Metodologia do trabalho científico: métodos e técnicas da pesquisa e do trabalho acadêmico (2. ed.). Novo Hamburgo: Feevale.

Raposo, C. F. C. (2011). Overall equipment effectiveness: aplicação em uma empresa do setor de bebidas do polo industrial de Manaus. Produção Online, 11(3), 648-667. http://dx.doi.org/10.14488/1676-1901.v11i3.529.

Ribeiro, D. M., Correa, P. C., Rodrigues, D. H., \& Goneli, A. L. D. (2005). Análise da variação das propriedades físicas dos grãos de soja durante o processo de secagem. Food Science and Technology, 25(3), 611-617. http://dx.doi.org/10.1590/S0101-20612005000300035.

Rigoto, M. S., \& Natti, E. R. T. (2014). Estudo para otimização dos processos em uma fábrica de tubos de concreto. In Anais do XXXIV Encontro Nacional de Engenharia de Produção. Curitiba: ABEPRO.

Rodrigues, C. L. C. (2010). Desenvolvimento de um sistema automático para um secador de produtos agrícolas (Tese de doutorado). Universidade Federal de Viçosa, Viçosa.

Schmidt, L., Lorencena, M. C., \& Teixeira, M. (2017). Controle de operações em secadores de grãos com redução do consumo de recursos naturais. In Anais do Computer on the Beach (pp. 170-179). Pato Branco PR: UTFPR.

Silva, D. C. S., Lucena, A. D., Medeiros, L. D. D., Costa, D. O., \& Andrade, J. T. D. (2015). Estudo de indicadores chave de desempenho em manutenção e construção de uma 
dashboard em uma indústria do ramo petrolífero. In Anais do XXXV Encontro Nacional de Engenharia de Produção. Fortaleza: ABEPRO.

Silva, J. P. A. R. (2009). OEE a forma de medir a eficácia dos equipamentos.

Silva, L. C. (2004). Secagem de grãos. Revista Grãos Brasil: da Semente ao Consumo, 3(14), 10-14.

Silva, L. C. (2006). Operação de secadores cascata (Boletim Técnico Agais, Vol. 2, No. 6). Vitória: Universidade Federal do Espírito Santo. Retrieved in 2017, September 5, from http://www.agais.com/manuscript/ag0206_operacao_secador_cascata.pdf

Silva, M. S., \& Derzi, L. R. G. D. (2016). Aplicação da ferramenta tpm para otimização da eficiência para global em máquina de conformação de tampa básica de alumínio latas de bebidas. In Anais do XXXVI Encontro Nacional de Engenharia de Produção. João Pessoa: ABEPRO.

Slack, N., Chambers, S., \& Johnston, R. (2002). Administração da produção (2. ed.). São Paulo: Atlas.

Stortte, J. M. C., Zafra, F. M., Silva, D. C., Detregiachi, E., Fo., \& Zachi, J. M. (2014). Aplicação do indicador OEE como ferramenta para aumento da eficiência em uma caldeira. In Anais do XXXIV Encontro Nacional de Engenharia de Produção. Curitiba: ABEPRO.

United States Departament of Agriculture - USDA. (2017). Commodities and production. Washington.

Vinha, E. P., \& Mota, R. O. (2014). A importância da correta aplicação do OEE: um estudo de caso em uma empresa produtora de rações da cidade de rio pomba mg. Administração de Empresas em Revista, 13(14), 192-203. Retrieved in 2018, July 27, from http://revista.unicuritiba.edu.br/index.php/admrevista/article/view/1033/720

Weber, E. A. (2005). Excelência em beneficiamento e armazenagem de grãos. Canoas: Salles.

Xing, Q., Wit, M., Kyriakopoulou, K., Boom, R. M., \& Schutyser, M. A. I. (2018). Protein enrichment of defatted soybean flour by fine milling and electrostatic separation. Innovative Food Science \& Emerging Technologies, 50, $42-49$.

http://dx.doi.org/10.1016/j.ifset.2018.08.014. 